\title{
Do fungal pathogens drive density-dependent mortality in established seedlings of two dominant African rain-forest trees?
}

\author{
Julian M. Norghauer*,1, David M. Newbery*, Leho Tedersooł and George B. Chuyong $\ddagger$ \\ * Institute of Plant Sciences, University of Bern, Altenbergrain 21, CH-3013, Bern, Switzerland \\ $\dagger$ Institute of Ecology and Earth Sciences, University of Tartu, 40 Lai Street, 51005 Tartu, Estonia \\ $\ddagger$ Department of Plant and Animal Sciences, University of Buea, P.O. Box 63, Buea, SW Province, Cameroon \\ (Accepted 6 January 2010)
}

\begin{abstract}
Where one or a few tree species reach local high abundance, different ecological factors may variously facilitate or hinder their regeneration. Plant pathogens are thought to be one of those possible agents which drive intraspecific density-dependent mortality of tree seedlings in tropical forests. Experimental evidence for this is scarce, however. In an African rain forest at Korup, we manipulated the density of recently established seedlings $(\sim 5-8 \mathrm{wk}$ old; low vs. high-density) of two dominant species of contrasting recruitment potential, and altered their exposure to pathogens using a broad-spectrum fungicide. Seedling mortality of the abundantly recruiting subcanopy tree Oubanguia alata was strongly density-dependent after $7 \mathrm{mo}$, yet fungicide-treated seedlings had slightly higher mortality than controls. By contrast, seedling mortality of the poorly recruiting large canopy-emergent tree Microberlinia bisulcata was unaffected by density or fungicide. Ectomycorrhizal colonization of $M$. bisulcata was not affected by density or fungicide either. For O. alata, adverse effects of fungicide on its vesicular arbuscular mycorrhizas may have offset any possible benefit of pathogen removal. We tentatively conclude that fungal pathogens are not a likely major cause of density dependence in O. alata, or of early post-establishment mortality in M. bisulcata. They do not explain the latter's currently very low recruitment rate at Korup.
\end{abstract}

Key Words: central Africa, density-dependence, fungicide, Korup National Park, Microberlinia bisulcata, Oubanguia alata, plant pathogens, seedling mortality, tropical rain forest

\section{INTRODUCTION}

Pathogens are widespread organisms that can help to maintain local plant diversity and composition in temperate zones (Bradley et al. 2008, Burdon \& Chilvers 1982, Gilbert 2002, Petermann et al. 2008). In wet tropical zones, fungal pathogens are thought to play a similar role in forests by driving intraspecific densitydependence in very young trees (Turner 2001; reviewed by Freckleton \& Lewis 2006; fungal pathogens here include Oomycota, see Money 1998). Density-dependent growth and mortality in trees $>1 \mathrm{~cm}$ dbh is common in these communities (reviewed by Zimmerman et al. 2008), but is likely more intense in the seed-to-seedling transition and among young seedlings (Harms et al. 2000, Queenborough et al. 2007, Webb \& Peart 1999), as well as in wetter forests with low seasonality in

\footnotetext{
${ }^{1}$ Corresponding author. Email: julian.norghauer@ips.unibe.ch
}

which pathogens and herbivores may be more abundant (Givnish 1999). What mechanisms generate negative density dependence in these systems remains unclear, however. It is well known that damping-off type pathogens can disproportionately kill more germinating seedlings near parent trees where host density peaks (Augspurger 1983, 1984; reviewed by Gilbert 2002, 2005). But for pathogens to promote species co-existence they ought to have a negative effect on locally dominant plant species at one or more life-stages (Freckleton \& Lewis 2006, Gilbert 2005). Conversely, their absence may promote dominance in some forests.

In African forests, the impacts of pathogens on tree seedlings have been little studied compared with elsewhere (Hood et al. 2004). This is surprising because at small spatial scales a fair number of canopy-emergent species can form clusters of adults marked by a dearth of saplings and larger juveniles (Jones 1956). This perplexing phenomenon suggests that regeneration is occurring in parallel beyond these clusters (Aubréville 
1938) and leaves open the possibility that in these high-density adult clusters, one or more factors, such as pathogens, may be putting a brake on local conspecific recruitment (Connell 1971, Janzen 1970). Understanding what factors weaken local dominance by a tree species in a given location is just as important as understanding what processes gave rise to its dominance in the first place (Watt 1947).

For example, in lowland rain forest of Korup National Park in Cameroon, the locally dominant grove-forming canopy tree, Microberlinia bisulcata A. Chev. (Caesalpiniaceae), is ectomycorrhizal but currently regenerating poorly because of too few juveniles in the 1$30 \mathrm{~cm}$ dbh size class to replace its larger adults (Newbery et al. 1998). This very limited regeneration, however, is not for a lack of established seedlings, which are widely abundant following masting events. The vast majority die in the next 2-5 y for unknown reasons (Green \& Newbery 2002, Newbery et al. 2006a). By contrast, co-occurring with M. bisulcata is Oubanguia alata Bak.f. (Scytopetalaceae), a more shade-tolerant and widespread arbuscular mycorrhizal tree rarely exceeding $50 \mathrm{~cm} \mathrm{dbh}$ (Newbery et al. 1988, 2002). This species dominates the subcanopy, and is currently regenerating well, unlike M. bisulcata (D. M. Newbery \& X. M. van der Burgt, unpubl. data). It is conceivable then, that pathogens could play an important role in density-dependent dynamics of already established seedlings, and not just in seed-to-seedling transition alone (Watt 1919, Webb \& Peart 1999, Queenborough et al. 2007). Yet explicit investigations at the post-establishment stage remain scarce. Recently, however, for the seed-to-seedling transition, Bell et al. (2006) convincingly showed that manipulating in situ density of germinating seedlings coupled to fungicide application provides for a direct assessment of pathogens' role in tree seedling dynamics.

Here, we applied the experimental approach of Bell et al. (2006) but to recently established seedlings of M. bisulcata and O. alata ( $\sim 5-8 \mathrm{wk}$ old $)$ in one of the wettest tropical regions of the world. Of the two, M. bisulcata is our main interest because of its poor regeneration following establishment. This timing of plant age was chosen to correspond with the October-November initiation of previous census surveys made of established Microberlinia seedlings at Korup after masting events in 1995 and 1997 (Green \& Newbery 2001a, 2002; Newbery et al. 2002, 2006a). We hypothesized that pathogens can kill seedlings of $M$. bisulcata and $O$. alata, and that greater seedling density enhances this effect (Connell 1971, Freckleton \& Lewis 2006, Janzen 1970). Thus we expected a strong interaction between seedling density and application of a fungicide (Bell et al. 2006). For $M$. bisulcata, a further aim was to investigate cryptic effects of pathogens and host-density on seedling height and leaf area, and to check for ectomycorrhizal colonization of seedlings' roots.

\section{METHODS}

\section{Study site and species}

The experiment was carried out in lowland tropical rain forest in Cameroon at a site close to Korup National Park on the Isangele Road $\left(4^{\circ} 58^{\prime} \mathrm{N}, 8^{\circ} 48^{\prime} \mathrm{E}\right.$; $98 \mathrm{~m}$ asl). It was formerly part of the Park until its annexation in 1995. The forest grows on nutrient-poor sandy soils. Average rainfall in the region is 180 to $900 \mathrm{~mm}$ per month in the March-November wet season, but $\leq 50 \mathrm{~mm}$ per month in the December-February dry season (overall, $\sim 5100 \mathrm{~mm} \mathrm{y}^{-1}$, based on monthly averages from 1988-2004 measured at PAMOL Bulu station $\sim 7 \mathrm{~km}$ away from Isangele Road, Newbery et al. 2006b). This forest is similar in stand structure to that found in the main 'P-plot' $\left(5^{\circ} 1^{\prime} \mathrm{N}, 8^{\circ} 49^{\prime} \mathrm{E}\right)$ situated $\sim 4.2 \mathrm{~km}$ north in Korup (Newbery et al. 2002), except that it lacks Tetraberlinia bifoliolata (Harms) Haumann, a co-dominant canopy tree species. The site contains a small grove of M. bisulcata adults which masted in 2007 as well as many $O$. alata adults, which also fruited in 2007. Abundant M. bisulcata seedlings, some still with cotyledons attached, and O. alata seedlings were seen on two visits in September 2007, by which time dispersal was over for both species. Although the phenology, dispersal and seedling dynamics of $O$. alata remain little studied, in previous work recently fallen seeds were collected in late July-early August for seed sowing and germination (Green \& Newbery 2001a, b). Thus, we assumed that O. alata dispersal in 2007 also occurred primarily in this time period, so that by the experiment's start (6-7 October 2007, see Figure 1) seedlings were established and at least 5 wk old. Details on species' traits indicative of their seed reserves are reported in Green \& Newbery (2001b).

Previous on-site work by Newbery et al. (2002) demarcated an 8.75-ha permanent forest plot $(250 \mathrm{~m} \times$ $350 \mathrm{~m}$ ) of 35 subplots of $50 \mathrm{~m} \times 50 \mathrm{~m}$ each. Seven of these subplots were fertilized by triple-superphosphate totalling $150 \mathrm{~kg} \mathrm{ha}^{-1}$ in November $1995-$ November 1997. We surmise that after $10 \mathrm{y}$ these applications of inorganic $\mathrm{P}$ had no residual effects in the soil (M. Isaac, pers. comm.). In terms of basal area, O. alata was ranked first in the $10-<50-\mathrm{cm}$ dbh size class with a basal area of $2.94 \mathrm{~m}^{2} \mathrm{ha}^{-1}$, and M. bisulcata was ranked first in the $\geq 50$-cm stem diameter (above buttress) class, with $5.59 \mathrm{~m}^{2} \mathrm{ha}^{-1}$ (Newbery et al. 2002).

\section{Experimental design}

We used a balanced randomized design stratified at three spatial scales $\left(2500,625\right.$ and $\left.4 \mathrm{~m}^{2}\right)$. A map of trees $\geq 50 \mathrm{~cm}$ diameter indicated that 15 of the 35 subplots had at least one living $M$. bisulcata adult in 1995. When each of the 15 subplots was further divided into four 
sub-subplots of $25 \mathrm{~m} \times 25 \mathrm{~m}$ each, we found that 33 out of the resulting $60(15 \times 4)$ had an adult tree present. In each of these sub-subplots, a random Cartesian coordinate was used as a starting point to search for a dense patch of recently established $M$. bisulcata seedlings, whereupon a 2-m $\times 2-\mathrm{m}$ experimental plot unit (EPU) was set up. All but two of these EPUs had at least $22 \mathrm{M}$. bisulcata seedlings $(\max .=78$, median $=40$, mean $=39.3)$; three more EPUs were added in three sub-subplots near a M. bisulcata adult to give a total of 36 EPUs (range of distances from EPUs to nearest adults: 5.4-22.4 m). For $O$. alata, we set up 18 EPUs in eight subplots with noticeable regeneration (range in density: 24-209 seedlings $\mathrm{m}^{-2}$ ). The experiment was installed on 1-5 October 2007.

Each EPU was split into four 1-m² quadrats to each of which were randomly assigned one of the four treatments (combinations of): density (low vs. high) $\times$ fungicide (sprayed vs. control). For M. bisulcata, the high-density quadrats were left as they were, whereas the lowdensity quadrats were hand-thinned down to one, two or three seedlings, depending on initial number of seedlings in the high-density treatment ( $>22$ down to three, $15-22$ to two, and $<15$ to one seedling). Handthinning involved plucking individual seedlings out of the ground as opposed to simply clipping them at the base of the stem. These one to three selected $M$. bisulcata seedlings were typically among the largest in leaf area and firmly rooted. They were individually marked with a numbered nail in the ground (total seedlings followed, $n=272$ ). We chose these healthy looking seedlings because we were interested in evaluating what happens post-establishment, and therefore needed to standardize their sizes and exposure to earlier influences. We assumed that these seedlings were equally susceptible to potential infections as those not selected for monitoring, and avoided seedlings near to the edges of quadrats yet also tried to have them sufficiently dispersed inside. In the high-density treatment an equal number of $M$. bisulcata seedlings (1-3) were similarly selected. Because greater plant size enhances seedling persistence in the understorey for many tropical trees (Turner 2001), the effects of pathogens and density on plant size were assessed for M. bisulcata only, the species of primary interest. For O. alata, seedlings in the low-density treatments were hand-thinned down to $\sim 10 \%$ of the total counts in the high-density quadrats. Oubanguia alata seedlings were not labelled for growth measurement.

\section{Fungal pathogen exclusion}

To protect recently established tree seedlings from pathogens, two quadrats of each EPU were treated with Ridomil Gold Plus ${ }^{\circledR}$ (Syngenta Crop Protection AG, Basel, Switzerland). This systemic fungicide has a broadspectrum activity against a variety of plant fungal root and stem diseases such as the oomycete orders Peronosporales and Pythiales, which include the aggressive damping-off pathogens Phytophthora and Pythium spp. The fungicide combines two active ingredients, copper hydroxide $(60 \%)$ and metalaxyl-M(6\%), a.k.a.mefenoxam (Demanou et al. 2004, Monkiedje et al. 2007; and references therein). In Cameroon it is used increasingly to control black pod disease on cacao tree farms, as well as diseases on a range of subsistence crops.

Fungicide powder was dissolved in stream water on-site using proportions as recommended by the manufacturer (50 g per $15 \mathrm{~L}$ water) and transferred to a 1-L plastic hand-held spraying bottle. To each $1-\mathrm{m}^{2}$ quadrat, $50 \mathrm{ml}$ of fungicide (equivalent to a concentration of $\sim 0.17 \mathrm{~g} \mathrm{~m}^{-2}$ ) was evenly sprayed across the ground to both soils and seedlings. The control quadrats received the same volume of water instead of fungicide solution. Five applications were made that tracked the decreasing seasonal rainfall in 2007; a sixth application was made in early 2008 (see arrows in Figure 1). In this way, a total of close to $1 \mathrm{~g} \mathrm{~m}^{-2}$ of fungicide was applied over a 14-wk period.

\section{Seedling mortality and light availability}

Seedling survival of $M$. bisulcata and O. alata were censused twice (Figure 1), and their light environment quantified because very low light levels, which can vary at a fine spatial scale (1-2 m), might affect their resistance to pathogens and hence survival in the forest understorey. Canopy photographs were taken at a height of $60 \mathrm{~cm}$ in the centre of each $1-\mathrm{m}^{2}$ quadrat using a hemispherical lens and a digital Nikon camera. Photographs were taken for both species at dusk in the dry season (1517 January 2008) and again for M. bisulcata only in the early wet season (21-22 April 2008) under overcast conditions. They were evaluated using our site's geographic coordinates but with default settings in the Gap-Light Analyzer software of Frazer et al. (1999) to obtain comparative measures of per cent canopy openness $(\% \mathrm{CO})$ and per cent daily photosynthetically active photon flux density (diffuse + direct \%PPFD). One of us (JMN) made all image threshold adjustments so as to achieve consistency and precision. We caution, however, that computed \%PPFD values from hemi-photos are prone to inaccuracy, and likely exceed absolute values. This is because light is scattered by foliage and the 'halo' effect intensifies under closed canopies with many small holes, creating an upward bias for sky area during threshold adjustments (Whitmore et al. 1993).

\section{Microberlinia bisulcata seedling size and growth}

Because pinnate leaves can vary widely in actual leaflet numbers present (1-28), we measured photosynthetic area by photographing seedlings and counting their 
leaflets on 22 November 2008 (Table 1). Relaxed heightmeasured from ground perpendicular to the tallest live part of the plant, irrespective of tissue type (i.e. stem, leaf, leaf petiole) - and just the numbers of whole leaves, however, were recorded first in the dry season (15 January 2008), and the same again plus number of leaflets 14-wk later on 22 April 2008 (Table 1). Values for the one to three $M$. bisulcata seedlings monitored per quadrat were averaged to not risk pseudo-replication, as in some instances they were close to one another (10 to $30 \mathrm{~cm}$ apart) and could not be considered statistically independent sample units.

\section{Harvested Microberlinia bisulcata seedlings}

To control for spatial heterogeneity, harvesting was restricted to those EPUs that had at least one survivor in each of their four (treatment) quadrats $(n=20)$. Eighty seedlings were carefully removed from the ground on 23-24 April 2008. Their root systems were temporarily wrapped in soft moist litter to prevent desiccation, and transported out of the forest in plastic bags. Roots were stored in Eppendorf tubes containing CTAB buffer (100 mM Tris- $\mathrm{HCl}$ ( $\mathrm{pH} 8.0$ ), $1.4 \mathrm{M} \mathrm{NaCl}, 20 \mathrm{mMEDTA}, 1 \%$ cetyl trimethyl ammonium bromide). Using a stereomicroscope with $10-50 \times$ magnification, root tips were scored for presence of a fungal mantle. Leaf phosphorus (P) and nitrogen $(\mathrm{N})$ were determined colorimetrically (molybdenum-blue and modified Bertholet reactions, respectively) in diluted $\mathrm{H}_{2} \mathrm{SO}_{4} / \mathrm{Se} / \mathrm{H}_{2} \mathrm{O}_{2}$ digests using an automated continuous-flow spectrophotometric system (Skalar Analytical, Breda, the Netherlands).

\section{Data analysis}

The proportions of seedlings alive after $c .7$ mo were analysed using ANCOVA (analysis of covariance) and GLM (generalized linear model; Galwey 2006) for O. alata and M. bisulcata respectively. In both models, density, fungicide and their interaction were fixed factors, and the light variables $\log (\% \mathrm{CO})$ and $\log (\% \mathrm{PPFD})$ were included as covariates. The GLM assumed a binomial error distribution by using the logit-link function: it allowed for heterogeneity to be fitted as a dispersion parameter (Galwey 2006). For M. bisulcata, proportions were limited to the five values: $0,1 / 3,1 / 2,2 / 3$ and 1 . For 0 . alata, model checking revealed that ANCOVA, using the arcsine square-root transformation with EPU as blocking factor, satisfied assumptions of the linear model better than GLM, especially in terms of heteroscedasticity. GLMM (generalized linear mixed model), which treated EPU as a random factor, was used to analyse the proportion of intact tips that had EcMs; this taking root mass and total number of tips into account as covariates. Two-factor ANCOVA was used to evaluate plant size, and its change, in $M$. bisulcata with untransformed light measures as covariates and EPU as the blocking term. Analyses of leaf $\mathrm{P}$ and $\mathrm{N}$, and root-shoot ratios, were limited however to 40 and 48 seedlings, respectively, because of insufficient material. Statistical analyses were made in GenStat vers. 10 (VSN Int., Oxford, UK), and assumptions checked for all models.

\section{RESULTS}

\section{Microberlinia bisulcata seedling survival}

Mortality of $M$. bisulcata seedlings at 14 wk was very low: only $7.0 \%$ (19 out of 272) had died (Figure 1a). Even after $28 \mathrm{wk}$, density and fungicide treatments had negligible effects on seedling mortality (GLM, main effects, respectively, $\mathrm{P}=0.83$ and $\mathrm{P}=0.51$; Figure $1 \mathrm{a}$ ), with no interaction evident $(\mathrm{P}=0.87)$. Probability of seedling survival increased significantly with distance away from the nearest $M$. bisulcata adult tree $\left(t_{1,135}=2.84\right.$, $\mathrm{P}=0.005)$, to a lesser degree on $\log (\% \mathrm{PPFD}$ in January) $\left(t_{1,135}=2.30, \mathrm{P}=0.023\right)$, and not on $\log (\% \mathrm{CO}$ in January) $(\mathrm{P}=0.085)$. Light variables in January 2008 were positively correlated with those in April 2008 ( $\mathrm{P}<$ $0.0001)$. Mean \% CO across the 144 quadrats in January and April 2008 was $3.60 \%$ (range $=2.14-5.78$ ) and $3.76 \%$ (range $=2.35-5.07$ ), respectively; derived \%PPFD from hemi-photos averaged $6.71 \%$ (range $=2.86-13.9)$ and $6.92 \%$ (range $=4.67-11.4$ ), respectively. Overall, $55 \%$ (150 out of 272) of M. bisulcata seedlings survived the 28 wk to April 2008.

\section{Oubanguia alata seedling survival}

In contrast to M. bisulcata, mortality was high in O. alata after $14 \mathrm{wk}$. At this time we found evidence of a conspecific density effect on 0 . alata mortality, with $\sim 1.6$ times higher proportion of seedlings surviving in the low-density than high-density treatment (Figure 1b). Pooling all quadrats, $61 \%$ of 0 . alata seedlings died (1788 out of 2898 ).

After $28 \mathrm{wk}$, the main effect of density was very strong $\left(F_{1,49}=70.9, \mathrm{P} \ll 0.0001\right.$; Figure $\left.1 \mathrm{~b}\right)$, with the proportion of seedlings alive in low-density quadrats more than twice that in high-density ones, irrespective of fungicide treatment (interaction term, $\mathrm{P}=0.37$ ). At this time, however, a relatively weak negative effect of fungicide was detected $\left(F_{1,49}=6.44\right.$, $\mathrm{P}=0.014)$ in which $\sim 25 \%$ more control seedlings than sprayed seedlings survived (mean \pm SE: $0.44 \pm 0.06$ vs. $0.34 \pm 0.05)$. Light availability was a positive predictor of seedling survival among EPUs when expressed as log 


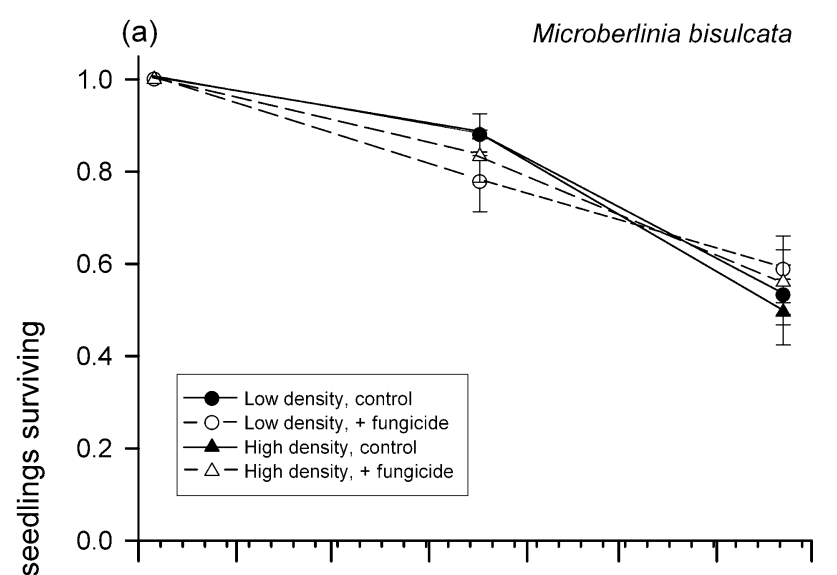

(b) Oubanguia alata

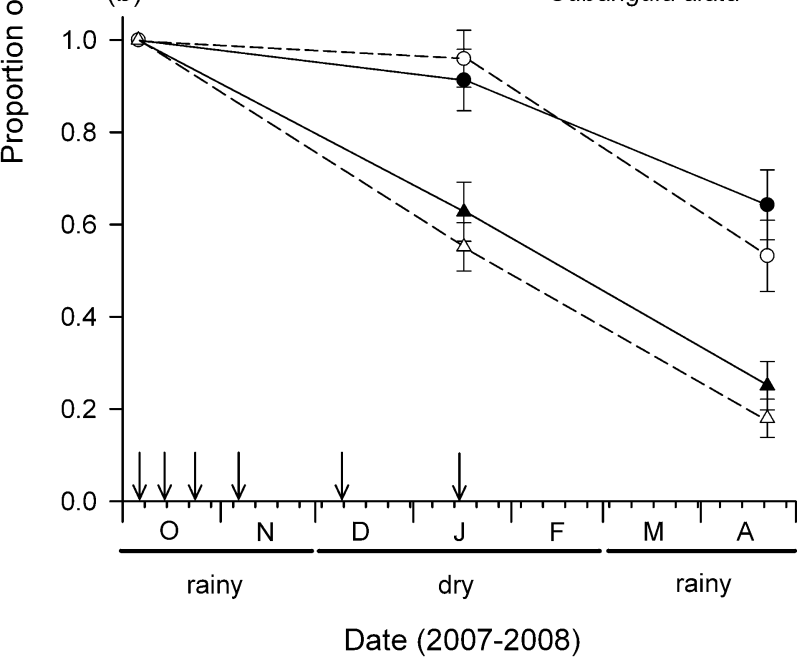

Figure 1. Mean ( \pm SE) proportions of established seedlings of Microberlinia bisulcata (a) and Oubanguia alata (b) trees surviving at the Isangele Road, Korup, Cameroon, in an experiment that manipulated their density and exposure to fungal pathogens over $28 \mathrm{wk}$ (M. bisulcata, $\mathrm{n}=144$ quadrats; $O$. alata, $\mathrm{n}=72$ ). Seedlings were censused twice, once in the dry season (17 January 2008), and again in the early wet season (22 April 2008) after the experiment's installation on 1-5 October 2007. On the $\mathrm{x}$-axis minor ticks denote 1-wk intervals. Vertical arrows indicate when fungicide applications were made (total of six). Horizontal bars indicate seasonality in rainfall.

(\%PPFD), but not $\log (\% \mathrm{CO})(\mathrm{P}=0.027$ and $\mathrm{P}=0.28$, respectively). Mean \%CO across the 72 quadrats in January 2008 was $3.76 \%$ (range $=2.13-5.72$ ) and derived \%PPFD from hemiphotos averaged 6.55\% (range $=2.60-11.5)$. By the end of the experiment $25 \%$ of all O. alata seedlings were alive and $41 \%$ (740 out of 1788) had survived between censuses.

\section{Microberlinia bisulcata seedling size and growth}

In early November 2007 the M. bisulcata seedlings monitored had similar number of leaflets between and among treatments (all model terms, $\mathrm{P}>0.20$ ). However, by the end of the experiment, in April 2008, seedlings growing at low density without fungicide (L-) had significantly more leaflets (mean \pm SE, $94 \pm 6.4$ ) than seedlings at low density with fungicide $(\mathrm{L}+, 70 \pm 6.8)$ or high-density with fungicide $(\mathrm{H}+, 74 \pm 8.3)$, but not the $\mathrm{H}-(81 \pm 8.2)$. These means were compared with Ryan-Einot-Gabriel-Welsch test following a significant interaction $\left(F_{1,89}=8.00, \mathrm{P}=0.006\right)$. This pattern was present in the number of leaves in April (interaction, $\left.F_{1,89}=8.40, \mathrm{P}=0.005\right)$ and the net change in the number of leaflets between November and April (interaction, $F_{1,89}=4.34, \mathrm{P}=0.041$ ). In these cases seedlings in all treatment combinations except for L( $7 \pm 5.3$ leaflets) experienced net negative growth (i.e. fewer leaflets in April than in November; mean change in leaflets for $\mathrm{L}+,-14 \pm 6.2$; for $\mathrm{H}+,-7 \pm 7.3$; for $\mathrm{H}-$, $-5 \pm 8.1$ ). Seedling heights in January and April were not influenced by density and/or fungicide treatments, nor were changes in height (on average $<1 \mathrm{~cm}$ ) between censuses $(\mathrm{P}>0.20)$. Table 1 summarizes the size and growth for the entire sample (treatments pooled).

\section{Harvested Microberlinia bisulcata seedlings}

EcM colonization among the 80 harvested M. bisulcata seedlings did not differ significantly among densities or treatments, and nor was the interaction significant $(\mathrm{P}>0.38)$. The four treatment combinations each had mean EcM values of $89-90 \%$ in spite of the wide range of total intact tips found (range, 4-143 tips; mean $\pm \mathrm{SE}=64 \pm 4$ ). Mean \%EcM per EPU did not vary significantly with log-transformed distance to nearest M. bisulcata adult (linear regression, $\mathrm{n}=20, \mathrm{P}=0.50$ ). Root dry mass did not vary across densities and treatments $(\mathrm{P}>0.23)$. Concentrations of log-transformed foliar $\mathrm{P}$ were $15 \%$ higher in sprayed than control leaflets (twofactor ANOVA, $3.62 \pm 0.16$ vs. $3.12 \pm 0.14 \mathrm{mg} \mathrm{g}^{-1}$; $\left.F_{1,39}=10.8, \quad \mathrm{P}=0.003\right)$ but concentrations of logtransformed $\mathrm{N}$ did not differ significantly among treatments ( $\mathrm{P}>0.12$ for all three model terms). The lower part of Table 1 summarizes the above response variables for the harvested seedlings (treatments pooled).

\section{DISCUSSION}

We can place our experiment in the context of previous work at Korup to show how similar were the seedling dynamics for Microberlinia bisulcata. Survival to April 2008 (55\%) was greater than that observed in 1997 at the Isangele Road plot (25-30\%; Newbery et al. 2002), but less than in 1995 (70\%) and equivalent to 1997 (50$55 \%$ ) in the main grove P-plot at Korup (Newbery et al. 
Table 1. Size and growth of surviving Microberlinia bisulcata tree seedlings (n) recorded in the fungicide experiment at the Isangele Road plot, Korup. Cameroon, with root mass, percentage of intact root tips colonized by ectomycorrhizal fungi (EcM) and seedling leaflet nutrient concentrations of a harvested subset of plants.

\begin{tabular}{|c|c|c|c|}
\hline Response variables & Mean \pm SE & Range & $\mathrm{n}$ \\
\hline \multicolumn{4}{|l|}{ Height $(\mathrm{cm})$} \\
\hline January 2008 & $19.3 \pm 0.19$ & $12.8-23.6$ & 130 \\
\hline April 2008 & $19.8 \pm 0.24$ & $(11.1-24.1)$ & 101 \\
\hline change & $0.784 \pm 0.138$ & $(-3.3$ to 6.5$)$ & 101 \\
\hline \multicolumn{4}{|l|}{ No. of leaves } \\
\hline January 2008 & $4.3 \pm 0.072$ & $(1-6.5)$ & 130 \\
\hline April 2008 & $4.5 \pm 0.149$ & $(0-9)$ & 101 \\
\hline change & $-0.092 \pm 0.146$ & $(-5$ to 3$)$ & 101 \\
\hline \multicolumn{4}{|l|}{ No. of leaflets } \\
\hline November 2007 & $81.7 \pm 1.48$ & $(21.5-132)$ & 141 \\
\hline April 2008 & $80.1 \pm 3.77$ & $(3-188)$ & 101 \\
\hline change & $-4.53 \pm 3.40$ & $(-79$ to 124$)$ & 101 \\
\hline Root dry mass (mg) & $88 \pm 5$ & $(29-276)$ & 80 \\
\hline Root/shoot mass ratio & $0.31 \pm 0.03$ & $(0.07-0.81)$ & 48 \\
\hline $\operatorname{EcM}(\%)$ & $89.1 \pm 1.27$ & $(50-100)$ & 80 \\
\hline Leaf concentration $\left(\mathrm{mg} \mathrm{g}^{-1}\right): \mathrm{N}$ & $30.3 \pm 0.4$ & $(24.5-36.9)$ & 40 \\
\hline$: P$ & $3.37 \pm 0.11$ & $(2.07-4.65)$ & 40 \\
\hline
\end{tabular}

1998, 2006a). Overall, our mortality value was close to the average of these other results.

Unlike previous studies, we explored pathogen effects on the survivorship of established seedlings because strong negative density-dependence is not limited to the seed-to-seedling transition of trees (Queenborough et al. 2007, Webb \& Peart 1999). Our results suggest that pathogens did not hasten the mortality of young tree seedlings $(\sim 5-8 \mathrm{wk}$ old $)$ in the African rain-forest understorey. Mortality over the 7-mo period of study was density-independent for M. bisulcata, but it was strongly density-dependent for Oubanguia alata: in the latter case it was likely not due to pathogen activity. There is the remote possibility that in spite of its broad-spectrum activity, the fungicide we used was ineffective against a putatively virulent pathogen on $O$. alata seedlings. Alternatively, uninvestigated factors such as herbivory by insects and/or mammals, or intraspecific competition for resources, may have been responsible for the nonrandom O. alata mortality we detected.

Why sprayed seedlings of the non-ectomycorrhizal O. alata had higher mortality than controls by the end of the experiment is unclear. Possibly, vesiculararbuscular mycorrhizal root colonization was checked by the fungicide, as in the study of Hood et al. (2004). When applied in a single dose of $\geq 1 \mathrm{~g} \mathrm{~m}^{-2}$, Ridomol Gold Plus slightly stimulated $\mathrm{N}$ and $\mathrm{P}$ mineralization in trials on sandy loam soils at Yaoundé, Cameroon (Demanou et al. 2004), although when the equivalent of $\sim 0.9 \mathrm{~g} \mathrm{~m}^{-2}$ was applied in another trial at the same site it did not significantly affect soil $\mathrm{N}$ and $\mathrm{P}$ availability (Monkiedje et al. 2007). This suggests that the saprophytic fungi involved in decomposition had been little affected by the fungicide. Alternatively, the fungicide may have prevented the colonization of foliar endophytes that can protect leaves from pathogens (Arnold 2008).

A negligible pathogenic effect on seedling survival may be explained by insufficiently high host density for virulence (Burdon \& Chilvers 1982), in spite of masting in $M$. bisulcata trees. The maximum densities for O. alata and M. bisulcata were 209 and $23 \mathrm{~m}^{-2}$ seedlings respectively. These values were much lower than the 416-1018 germinating seedlings $\mathrm{m}^{-2}$ for the subcanopy tree, Sebastiania longicuspis, reported by Bell et al. (2006). Conversely, density may not be crucial for seedling susceptibility to pathogens in this forest: O. alata and $M$. bisulcata densities exceeded those reported for two of three trees (out of seven species) for which dampingoff pathogens killed more seedlings near to (vs. far from) parent trees in Panama (Augspurger 1984). Another intriguing explanation is that the very low soil fertility and high sand content at our site has selected for strong plant resistance against fungal diseases, in spite of the very wet conditions most of the year (Givnish 1999).

There are two caveats to our above interpretations, however. First, our results for either species could have changed over a longer census period: one that included a full rainy season with seedlings spending more time in the shade. Second, however unlikely, it is not impossible that a different fungicide may have yielded a different outcome for seedling dynamics of either species. Clearly, long-term experimental field studies of pathogens' impact should be undertaken, but these will require a very large sample of starting seedlings. In addition, we cannot discount possible pathogenic effects on seeds or during seedling emergence - for example, density-dependent mortality was strong in M. bisulcata over $6 \mathrm{wk}$ in the brief seed-toseedling transition at the P-plot site in Korup National Park (Norghauer \& Newbery, in press). Earlier, in the 1995 mast event, an unidentified white fungus was noted on $36 \%$ of $M$. bisulcata seeds/seedlings monitored in Korup (Green \& Newbery 2002). It was seen again in 2004 and 2007 at Korup, but not at Isangele Road in 2007. Its absence at the latter site may be explained by the absence of Tetraberlinia bifoliolata trees (Newbery et al. 2002), which appear to act as key hosts for this seed-attacking fungus (Green \& Newbery 2002; J. M. Norghauer, unpubl. data).

The high and consistent levels of ectomycorrhizal (EcM) colonization on $M$. bisulcata roots across treatments matched the results of an earlier transplant experiment of Newbery et al. (2000). This suggests that the fungicide did not interfere with this symbiosis and presumably then not with nutrient uptake. By contrast, in Ghana, application of another metalaxyl-M-based fungicide (Fubol Gold ${ }^{\circledR}$ ) reduced colonization of arbuscular mycorrhizas on potted seedlings of the light-demanding tree Milicia 
regia, but increased seedling survival under low light conditions in a controlled herbivore-free setting (Hood et al. 2004). Although some orange-reddish fungicide residue persisted on $M$. bisulcata leaflets after spraying, this was likely more a deterrent than an attractant to insect herbivores (Karageorgou et al. 2008). A more plausible explanation for diminished leaf area of sprayed $M$. bisulcata seedlings was slight phytotoxicity caused by $\mathrm{Cu}$ in the fungicide, possibly becoming more prominent in sandy soils (Tosselli et al. 2009). The Cu may also have contributed, albeit in an unknown way, to the elevated concentrations of $\mathrm{P}$ in sprayed leaflets of $M$. bisulcata (Sonmez et al. 2007). In passing we note that mean $P$ concentration (Table 1, lower part) in our 5-6-mo-old seedlings was $\sim 2$-fold that found in previous studies at Korup which harvested seedlings that were 15-35 mo old (1.43-1.72 $\mathrm{mg} \mathrm{g}^{-1}$ : Green \& Newbery 2001a, Newbery et al. 2000, 2002).

Previous published work investigating pathogenmediated mortality of tropical forest tree seedlings (Augspurger 1983, 1984; Augspurger \& Kelly 1984, Gilbert et al. 1994; reviewed by Gilbert 2002, 2005; Grogan \& Galvão 2006, Wenny 2000) has found mixed support for mortality increasing with seedling density (and/or declining with distance from conspecific adults) as predicted by the mechanism underpinning the hypotheses of Connell (1971) and Janzen (1970). More recently, soil pathogens in a Costa Rican forest did not increase seedling mortality of the dominant trees, but did exaggerate differences in shade tolerance among the 21 species examined (McCarthy-Neumann \& Kobe 2008). While the strength of pathogen effects and their degree of hostspecificity remains uncertain (Augspurger \& Wilkinson 2007, Gilbert 2005), without more field studies from African and South-East Asian forests, any generalizations, if indeed at all possible, will remain difficult.

In some tropical rain forests, especially in Africa, localized dominance of the canopy by one or few species is not uncommon (Aubréville 1938, Letouzey 1968). In many cases the species are locally well-adapted to their soil conditions and, to have reached such high abundances, recruitment could not have been strongly checked by disease or pest pressure (Richards 1996). The lack of early density-dependence in M. bisulcata is consistent with other evidence from Korup (Green \& Newbery 2002). Newbery et al. (2006a) found that seedling mortality also did not increase with seedling abundance, but it did with neighbouring conspecific basal area, suggesting that negative density-dependent effects are operating on a larger spatial scale than investigated in the present experiment. To have patches of high seedling density for manipulation however, EPUs had to be $<25 \mathrm{~m}$ from conspecific adult trees (mostly beneath their crowns), so density effects would have been found had they existed.
We conclude that the poor regeneration of M. bisulcata in the groves in Korup is unlikely to be due to fungal pathogen activity at the early post-establishment seedling stage. Instead, one or more other biological factors select against seedling survival in the vicinity of Microberlinia adults $(<25 \mathrm{~m})$, and at the same time select for larger seedlings and saplings further away $(>40 \mathrm{~m})$ from them (Newbery et al. 2010). It is quite possible that low susceptibility to pathogenic activity of Microberlinia and Oubanguia may have contributed to the promotion of their local dominance in Korup.

\section{ACKNOWLEDGEMENTS}

The authors thank S. Njibile and C. Ohka for field assistance, and the Cameroon Ministry of Forestry and Wildlife (MINEF) and Ministry of Scientific Research and Innovation (MINRESI) for research permission. The University of Buea provided logistic support and the University of Bern funded field operations. L.T. acknowledges funding from FIBIR-7434-JD0092.

\section{LITERATURE CITED}

ARNOLD, A. E. 2008. Endophytic fungi: hidden components of tropical community ecology. Pp. 298-312 in Carson, W. P. \& Schnitzer, S. A. (eds). Tropical forest community ecology. Wiley-Blackwell, Oxford.

AUBRÉVILLE, A. 1938. La Forêt Coloniale: Les forêts de l'Afrique occidentale française: Annales de l'Académie des Sciences Coloniales, v. IX. Société d'Editions Géographiques, Maritimes et Coloniales, Paris. 245 pp.

AUGSPURGER, C. K. 1983. Seed dispersal of the tropical tree, Platypodium elegans, and the escape of its seedlings from fungal pathogens. Journal of Ecology 71:759-771.

AUGSPURGER, C. K. 1984. Seedling survival of tropical tree species interactions of dispersal distance, light-gaps and pathogens. Ecology 65:1705-1712.

AUGSPURGER, C. K. \& KELLY, C. K. 1984. Pathogen mortality of tropical tree seedlings: experimental studies of the effects of dispersal distance, seedling density, and light conditions. Oecologia 61:211-217.

AUGSPURGER, C. K. \& WILKINSON, H. T. 2007. Host specificity of pathogenic Pythium species: implications for tree species diversity. Biotropica 39:702-708.

BELL, T., FRECKLETON, R. P. \& LEWIS, O. T. 2006. Plant pathogens drive density-dependent seedling mortality in a tropical tree. Ecology Letters 9:569-574.

BRADLEY, D. J., GILBERT, G. S. \& MARTINY, J. B. H. 2008. Pathogens promote plant diversity through a compensatory response. Ecology Letters 11:461-469.

BURDON, J. J. \& CHILVERS, G. A. 1982. Host density as a factor in plant disease ecology. Annual Review of Phytopathology 20:143166.

CONNELL, J. H. 1971. On the role of natural enemies in preventing competitive exclusion in some marine animals and in rain forest 
trees. Pp. 298-312 in den Boer, P. J. \& Gradwell, G. (eds). Dynamics of populations. Centre for Agricultural Publication and Documentation, Wageningen.

DEMANOU, J., MONKIEDJE, A., NJINE, T., FOTO, S. M., NOLA, M., TOUGET, S. H. Z. \& KEMKA, N. 2004. Changes in soil chemical properties and microbial activities response to the fungicide Ridomil Gold Plus Copper. International Journal of Environmental Research and Public Health 1:26-34.

FRAZER, G. W, CANHAM, C. D. \& LERTZMEN, K. P. 1999. Gap Light Analyzer (GLA) Version 2.0. Simon Fraser University, Burnaby, British Columbia and the Institute of Ecosystem Studies, Millbrook, New York. 36 pp.

FRECKLETON, R. P. \& LEWIS, O. T. 2006. Pathogens, densitydependence and the coexistence of tropical trees. Proceedings of the Royal Society B 273:2909-2916.

GALWEY, N. W. 2006. Introduction to mixed modeling: beyond regression and analysis of variance. John Wiley and Sons. Chichester. 366 pp.

GILBERT, G. S. 2002. Evolutionary ecology of plant disease in natural ecosystems. Annual Review of Phytopathology 40:13-43.

GILBERT, G. S. 2005. Dimensions of plant disease in tropical forests. Pp. 141-164 in Burslem, D. F. R. P., Hartley, S. E. \& Pinard, M. A. (eds). Biotic interactions in the tropics: their role in the maintenance of species diversity. Cambridge University Press, Cambridge.

GILBERT, G. S., HUBBELL, S. P. \& FOSTER, R. B. 1994. Density and distance to adult effects of a canker disease of trees in a moist tropical forest. Oecologia 98:100-108.

GIVNISH, T. J. 1999. On the causes of gradients in tropical tree diversity. Journal of Ecology 87:193-210.

GREEN, J. J. \& NEWBERY, D. M. 2001a. Shade and leaf loss affect establishment of grove-forming ectomycorrhizal rain forest tree species. New Phytologist 151:291-309.

GREEN, J. J. \& NEWBERY, D. M. 2001b. Light and seed size affect establishment of grove-forming ectomycorrhizal rain forest tree species. New Phytologist 151:271-289.

GREEN, J. J. \& NEWBERY, D. M. 2002. Reproductive investment and seedling survival of the mast-fruiting forest tree, Microberlinia bisulcata A. Chev. Plant Ecology 162:169-183.

GROGAN, J. \& GALVÃO, J. 2006. Factors limiting post-logging seedling regeneration by big-leaf mahogany (Swietenia macrophylla) in southeastern Amazonia, Brazil, and implications for sustainable management. Biotropica 38:219-228.

HARMS, K. E., WRIGHT, S. J., CALDERON, O., HERNANDEZ, A. \& HERRE, E. A. 2000. Pervasive density-dependent recruitment enhances seedling diversity in a tropical forest. Nature 404:493495.

HOOD, L. A., SWAINE, M. D. \& MASON, P. A. 2004. The influence of spatial patterns of damping-off disease and arbuscular mycorrhizal colonization on tree seedling establishment in Ghanaian tropical forest soil. Journal of Ecology 92:816-823.

JANZEN, D. H. 1970. Herbivores and the number of tree species in tropical forests. American Naturalist 104:501-528.

JONES, E. W. 1956. Ecological studies on the rainforest in Nigeria: IV (Continued). The plateau forest of the Okumu Forest Reserve. Journal of Ecology 44:83-117.
KARAGEORGOU, P., BUSCHMAN, P. \& MANETAS, Y. 2008. Red leaf color as a warning signal against insect herbivory: honest or mimetic? Flora 203:648-652.

LETOUZEY, R. 1968. Etude phytogéographique du Cameroun. P. LeChevalier, Paris. 508 pp.

MCCARTHY-NEUMANN, S. \& KOBE, R. 2008. Tolerance of soil pathogens co-varies with shade tolerance of across species of tropical tree seedlings. Ecology 89:1883-1892.

MONEY, N. P. 1998. Why oomycetes have not stopped being fungi. Mycological Research 102:767-768.

MONKIEDJE, A., SPITELLER, M., MANIEPI, S. J. N. \& SUKUL, P. 2007. Influence of metalaxyl- and mefenoxam-based fungicides on chemical and biochemical attributes of soil quality under field conditions in a southern humid forest zone of Cameroon. Soil Biology and Biochemistry 39:836-842.

NEWBERY, D. M., ALEXANDER, I. J., THOMAS, D. W. \& GARTLAN, J. S. 1988. Ectomycorrhizal rain-forest legumes and soil phosphorus in Korup National Park, Cameroon. New Phytologist 109:433450.

NEWBERY, D. M., SONGWE, N. C. \& CHUYONG, G. B. 1998. Phenology and dynamics of an African rainforest at Korup, Cameroon. Pp. 267308 in Newbery, D. M., Prins, H. H. T. \& Brown, N. D. (eds). Dynamics of tropical communities. Blackwell Science, Oxford.

NEWBERY, D. M., ALEXANDER, I. J. \& ROTHER, J. A. 2000. Does proximity to conspecific adults influence the establishment of ectomycorrhizal tree species in an African rain forest? New Phytologist 147:401-409.

NEWBERY, D. M., CHUYONG, G. B., GREEN, J. J., SONGWE, N. C., TCHUENTEU, F. \& ZIMMERMANN, L. 2002. Does low phosphorous supply limit seedling establishment and tree growth in groves of ectomycorrhizal trees in a central African forest? New Phytologist 156:297-311.

NEWBERY, D. M., CHUYONG, G. B., ZIMMERMANN, L. \& PRAZ, C. 2006a. Seedling survival and growth of three ectomycorrhizal caesalpiniaceous tree species in a Central African rain forest. Journal of Tropical Ecology 22:499-511.

NEWBERY, D. M., CHUYONG, G. B. \& ZIMMERMANN, L. 2006b. Mast fruiting of large ectomycorrhizal African rain forest trees: importance of dry season intensity, and the resource limitation hypothesis. New Phytologist 170:561-579.

NEWBERY, D. M., PRAZ, C. J., VAN DER BURGT, X. M., NORGHAUER, J. M. \& CHUYONG, G. 2010. Recruitment dynamics of the grovedominant tree Microberlinia bisulcata in African rain forest: extending the light response versus adult longevity concept. Plant Ecology 206:151-172.

NORGHAUER, J. M. \& NEWBERY, D. M. (in press). Recruitment limitation after mast-seeding in two African rain forest trees. Ecology. PETERMANN, J. S., FERGUS, A. J. F., TURNBULL, L. A. \& SCHMID, B. 2008. Janzen-Connell effects are widespread and strong enough to maintain diversity in grasslands. Ecology 89:2399-2406.

QUEENBOROUGH, S. A., BURSLEM, D. F. R. P., GARWOOD, N. C. \& VALENCIA, R. 2007. Neighborhood and community interactions determine the spatial pattern of tropical tree seedling survival. Ecology $88: 2248-2258$. 
RICHARDS, P. W. 1996. The tropical rain forest. Cambridge University Press, Cambridge. 575 pp.

SONMEZ, S., KAPLAN, M., SONMEZ, N. K., KAYA, H. \& UZ, I. 2007. Effect of both soil copper applications and foliar copper applications frequencies on macronutrients contents of tomato plants. Asian Journal of Chemistry 19:5372-5384.

TOSSELLI, M., BALDI, E., MARCOLONI, G., MALAGUTI, D., QUARTERIERI, M., SORRENTI, G. \& MARANGONI, B. 2009. Response of potted pear trees to increasing copper concentration in sandy and clay-loam soils. Journal of Plant Nutrition 31:2089-2104.

TURNER, I. M. 2001. The ecology of trees in the tropical rain forest. Cambridge University Press, Cambridge. 298 pp.

WATT, A. S. 1919. On the causes of failure of natural regeneration in British oakwoods. Journal of Ecology 7:173-203.

WATT, A. S. 1947. Pattern and process in the plant community. Journal of Ecology 35:1-22.
WEBB, C. O. \& PEART, D. R. 1999. Seedling density-dependence promotes co-existence of Bornean rain forest trees. Ecology 80:20062017.

WENNY, D. G. 2000. Seed dispersal, seed predation and seedling recruitment of a neotropical montane tree. Ecological Monographs 70:331-351.

WHITMORE, T. C., BROWN, N. D., SWAINE, M. D., KENNEDY, D., GOODWIN-BAILEY, C. I. \& GONG, W. K. 1993. Use of hemispherical photographs in forest ecology: measurement of gap size and radiation totals in a Bornean tropical rain forest. Journal of Tropical Ecology 9:131-151.

ZIMMERMAN, J. K, THOMPSON, J. \& BROKAW, N. 2008. Large tropical forest dynamics plots: testing explanations for the maintenance of species diversity. Pp. 89-117 in Carson, W. P. \& Schnitzer, S. A. (eds.). Tropical forest community ecology. Wiley-Blackwell, Oxford. 